\title{
Beneficial Effects of Calcium Chloride on Two Cyanobacterial Species under Sodium Chloride Stress
}

\author{
Mohamed G. Battah \\ Department of Botant, Faculty of Science, Benha University, \\ Benha, Egypt.
}

\begin{abstract}
7 XPOSURE of Anabaena constricta and Nostoc linckia to $0.2 \mathrm{M}$ $\mathrm{NaCl}$ induced a significant decrease in cell number, dry weight and pigments (chlorophyll "a" and carotenoids,). Also there was a decrease in glucose, protein and nitrogen contents. Addition of two different concentrations of $\mathrm{CaCl}_{2}(40$ and $60 \mathrm{mM})$ to the salinized cultures with both organisms induced a significant increase in growth and metabolites activities. Protein electrophoretic patterns of culture of $A$. constricta exposed to $0.2 \mathrm{M} \mathrm{NaCl}$ showed disappearance of one protein band at $77 \mathrm{KD}_{\mathrm{a}}$ and appearance of two protein bands at 171 and $70 \mathrm{KD}_{2}$ The addition of $40 \mathrm{mM} \mathrm{CaCl}$ to the salinized culture of A.constricta showed disappearance of one protein at $77 \mathrm{KDa}$ and appearance of three protein bands at 17, 61 and $162 \mathrm{KDa}$, while addition of $60 \mathrm{mM} \mathrm{CaCl} 2$ to salinized culture caused appearance of three protein bands at 18,58 and $138 \mathrm{KD}_{\mathrm{a}}$ as compared with control (salinized culture of $0.2 \mathrm{M} \mathrm{NaCl}$ alone). Addition of $0.2 \mathrm{M} \mathrm{NaCl}$ to culture of $N$ linckia and addition of $40 \mathrm{mM}$ or $60 \mathrm{mM} \mathrm{CaCl}$ to salinized culture showed no change of protein patterns as compared with control (culture without $\mathrm{NaCl}$ ) but differed in the percentage of intensity of proteins.
\end{abstract}

Keywords: Anabaena sp., Nostoc sp., Cyanobacteria, Salinity stress, Protein profile, Mitigate effect of $\mathrm{CaCl}_{2}$.

Salinity is an important deterrent to agriculture in many areas of the world. Salts not affect only the growth of plants but also inhibit the proliferation and activity of native or introduced microorganisms. Among these organisms, cyanobacteria have a fundamental role in supplying the crop plants with both nitrogen and growth regulators. This can increase crop yield and indirectly maintains the fertility status of soil.

High concentration of $\mathrm{NaCl}$ inhibits growth by increasing ionic and osmotic stress on cells (Brownell \& Nicolas, 1967). Since high intercellular concentrations of $\mathrm{Na}^{+}$are toxic to most biological systems, organisms that can live in $\mathrm{Na}$ rich environments. The ability to produce organic osmolytes to cope with ionic and osmotic stresses in the environment is common in $\mathrm{N}$-fixing cyanobacteria (Reed et al., 1986).

E-mail : maamay57@yahoo.com 
Exposure of Chlorococcum sp. to $0.2 \mathrm{M} \mathrm{NaCl}$ caused an increase in the biomass dry weight due to an increase in the cell size accompanied by massive appearance of secondary carotenoids. Maximum size was obtained after 2-3 days of cultivation (Masojidek et al., 2000). However, addition of $40 \mathrm{mM} \mathrm{NaCl}$ did not increase the carotenoids biosynthesis in the flagellated alga Haematococcus pluvialis (Hagen et al., 2001). The influence of salinity $(0.03-0.5 \mathrm{M} \mathrm{NaCl})$ on the physiological characteristics of fresh water cyanobacterium Synechococcus 6311 showed that intercellular granules disappeared, the density of the cytoplasm decreased and the appearance of DNA material was changed (Lefort -Tran et al., 1988).

Rai \& Abraham (1993), observed that with the increase in $\mathrm{NaCl}$ concentration (beyond $200 \mathrm{mM}$ ), the filaments of Anabaena doliolum were shorter with less heterocysts. Anand et al. (1994) studied the effect of salinity on the growth of cyanobacteria Chroococus minor, Gloeocapsa polydermatica, Oscillatoria salina, Lyngbya spiralis, Nostoc piscinate and Tolypothrix tenuis. They observed that Nostoc piscinate and T. fenuis released phycobilin pigments (phycocyanin and phycoerythrin) in the extracellular medium at salinities of $2.5-3.5 \%$. Zhao et al. (2005), indicated that the addition of nitrate could reduce the effect of salt stress on cultivated Nostoc flagelforme and enhance its salt resistance. El-Naggar et al. (2005) studied the effect of salinity stress $(0.3 \mathrm{M} \mathrm{NaCl})$ on the $\mathrm{N}$ metabolism of cyanobacterium Anabaena subcylindrica (Borge) in absence or presence of $\mathrm{CaCl}_{2}$ (0.03 or 0.05$)$. Salinity stress induced reduction in protein content, nitrogenase activity, some amino acids biosynthesis and nucleic acids content. Exogenous addition of $\mathrm{CaCl}_{2}$ to the culture medium alleviated the toxic action induced by salinity.

The aim of this research was to study the effect of low concentrations of $\mathrm{CaCl}_{2}$ on the growth of salinized cultures $(0.2 \mathrm{M} \mathrm{NaCl})$ of Anabaena constricta and Nostoc linckia.

\section{Materials and Methods}

\section{Organisms}

Two algal axenic cultures of filamentous heterocystous Anabaena constricta (Geitler) and Nostoc linckia (Roth) were isolated from saline alkali soils (pH 9.0), brought from cultivated fields of Sana'a Yemen, (Battah \& Khalil, 2008). The organisms were maintained in BG-11 medium (Stainer et al., 1971) at an illumination 3500 lux with regime $16 / 8$ hours light / dark at $27{ }^{\circ} \mathrm{C}$.

\section{Sodium chloride and calcium chloride treatments}

Cultures of $A$. constricta and $N$. linckia (7-9 days old) were inoculated into $0.2 \mathrm{M}$ $\mathrm{NaCl}$ parallel with control $(0.0 \mathrm{M} \mathrm{NaCl})$. Another set was inoculated into $0.2 \mathrm{M} \mathrm{NaCl}$ that also contained two different concentrations of $\mathrm{CaCl}_{2}(40$ and $60 \mathrm{mM})$. All flasks 
were incubated at a temperature $27 \pm 2^{\circ} \mathrm{C}$ and white light 5000 lux in regime $16 / 8$ hours light/dark.

\section{Growth estimation}

The changes in cell number were determined by Haemocytometer cell. The optical density was determined at $750 \mathrm{~nm}$ by spectreophotometer (Lefort Tran et al., 1988). The dry weight was estimated by Leganes et al. (1987). Chlorophyll "a" concentrations in cell were determined by spectrophotometric method of Jeffery \& Humphrey (1975). The carotenoids were determined according to Jensen \& Liaaen (1959). The phycobiloproteins were determined according to Bennet \& Bogorad (1973). The carbohydrate fractions of algal tissues were calculated as mg glucose/100 gm dry weight (Naguib, 1963). The total $\mathrm{N}$ content of the algal cultures was estimated by micro Kjeldahl as described by Jacobs (1958). The total soluble proteins were determined quantitavely by Lowery method (Lowery et al., 1951).

\section{Gradient gel electrophoresis}

Vertical polyacryamide gel electrophoresis (PAGE) was used as described by Laemmli (1970). Gel lanes were analyzed using gel documentation and analysis system consisting of a dark room, a transilluminator, an integrating CD Video camera and image software (AAB software).

\section{Statistical analysis}

Data were subjected to the proper statistical analysis according to Snedecor \& Cochran (1982).

\section{Results}

Addition of $0.2 \mathrm{M} \mathrm{NaCl}$ to cultures of Anabaena constricta or Nostoc linckia caused significant reduction in the cell number with values $34 \%$ in case of A.constricta and $23 \%$ in case of $N$. linckia after 15 days incubation period as shown in Fig. 1,2. Addition of 40 or $60 \mathrm{mM}$ of $\mathrm{CaCl}_{2}$ to salinized cultures caused an increase in the cell number of both organisms, being 1.42 fold and 1.55 fold high for $A$. constricta and $N$. linckia, respectively. The dry weight of both organisms in salinized culture $(0.2 \mathrm{M} \mathrm{NaCl}$ only) decreased in A. constricta and $N$. linckia and this decreasing amounted to $42.1 \%$ and $40 \%$, respectively . Addition of $40 \mathrm{mM}$ of $\mathrm{CaCl}_{2}$ to salinized cultures caused a significant increase in the dry weight of both organisms as compared with control cultures. This increase in A.constricta and $N$. linckia was nearly 1.81 and 1.83 fold, respectively, while addition of $60 \mathrm{mM} \mathrm{CaCl} \mathrm{Cl}_{2}$ to salinized culture of both organisms induced an increase of 1.6 and 1.5 fold in A. constricta and N. linckia, respectively, as compared with salinized culture after 15 days of incubation period (Fig. 1, 2). 


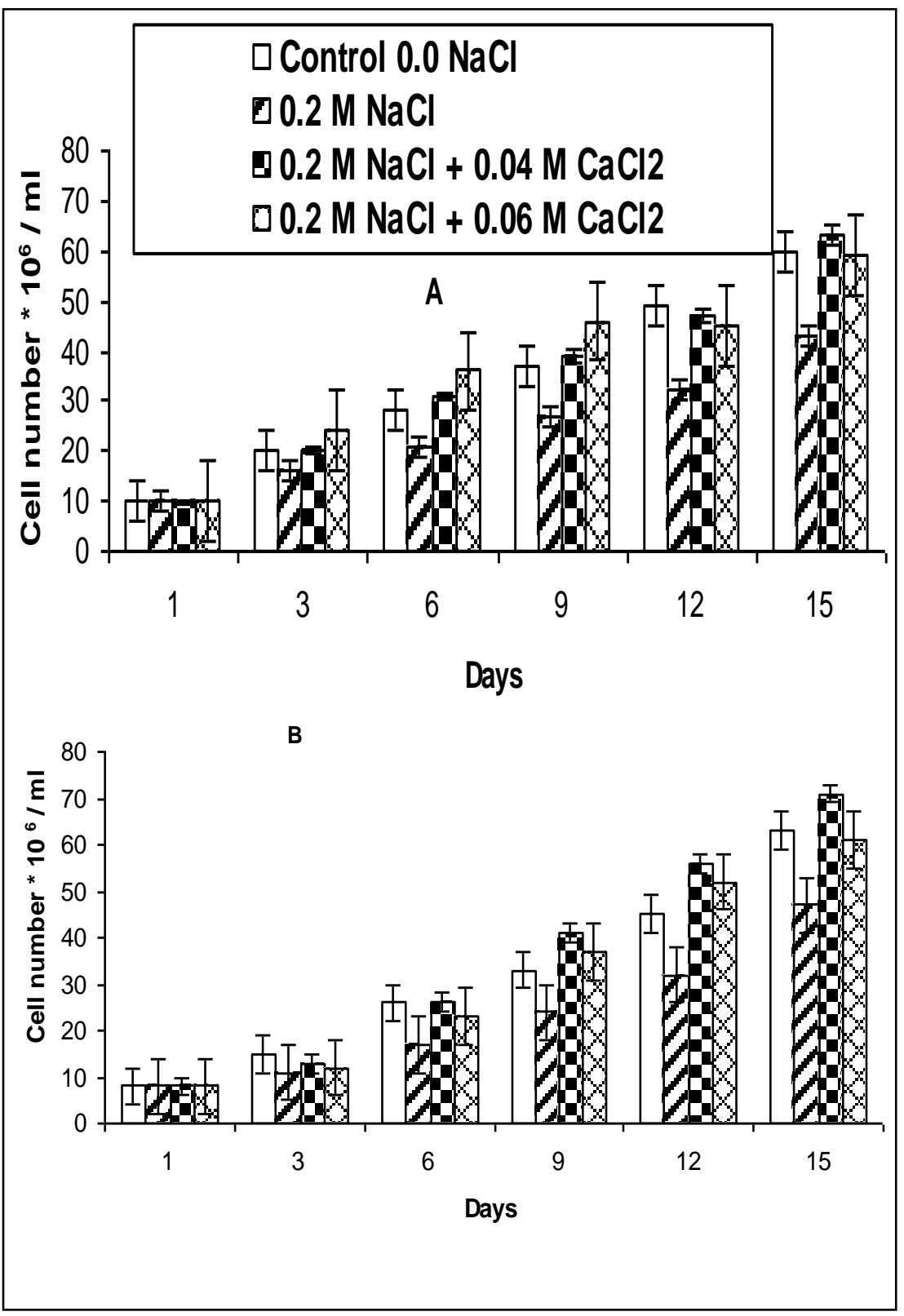

Fig. 1. Effect of two concentrations of $\mathrm{CaCl}_{2}$ on salinized culture of: A- A. constricta B- $N$. linckia (Cell number $\times 10^{6} / \mathrm{ml}$ ). 


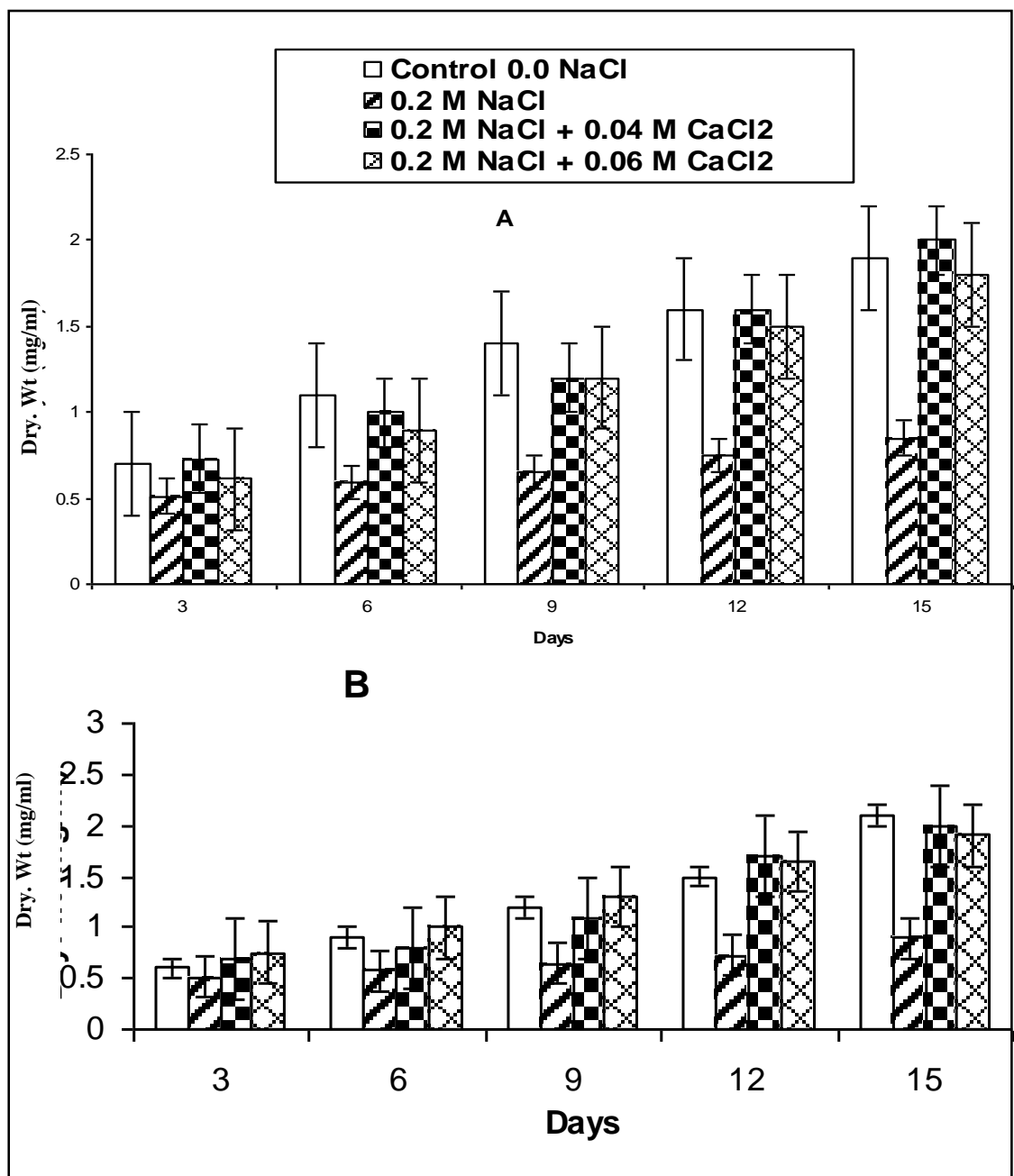

Fig. 2. Effect of two concentrations of $\mathrm{CaCl}_{2}$ on salinized culture of: A- A. constricta B- N. linckia (Dry.wt. mg/ml).

Application of $0.2 \mathrm{M} \mathrm{NaCl}$ only for both organisms resulted in sharp decrease in chl"a" content nearly to the control (Table 1). Addition of 40 or $60 \mathrm{mM} \mathrm{CaCl}_{2}$ to salinized culture of both organisms caused an increase in chl"a" and carotenoid contents as compared to salinized culture. The presence of $0.2 \mathrm{M} \mathrm{NaCl}$ in the culture medium caused a significant decrease in metabolic activities of $A$. constricta and $N$. linckia (Tables 2,3). Addition of 40 or $60 \mathrm{mM} \mathrm{CaCl}_{2}$ to salinized culture of both organisms induced significant increases in metabolic activities as glucose, $\mathrm{N}$ and protein contents. The effect of $40 \mathrm{mM} \mathrm{CaCl}$ was more prominent than the effect of $60 \mathrm{mM} \mathrm{CaCl}_{2}$. 
TABLE 1. Effect of two concentrations of $\mathrm{CaCl}_{2}$ on chlorophyll a and carotein contents of salinized cultures of different ages of $A$. constricta and $N$. linckia.

\begin{tabular}{|c|c|c|c|c|c|}
\hline \multirow{2}{*}{$\begin{array}{l}\text { Age } \\
\text { (days) }\end{array}$} & \multirow[t]{2}{*}{ Treatments } & \multicolumn{2}{|c|}{ A. constricta } & \multicolumn{2}{|c|}{ N. linckia } \\
\hline & & Chl"a" & "Car" & Chl"a" & "Car" \\
\hline \multirow[t]{4}{*}{3} & Control & $0.220 \pm 0.006$ & $0.280 \pm 0.006$ & $0.150 \pm 0.006$ & $0.320 \pm 0.006$ \\
\hline & $0.2 \mathrm{M} \mathrm{NaCl}$ & $0.060 \pm 0.006$ & $0.058 \pm 0.006$ & $0.013 \pm 0.003$ & $0.020 \pm 0.006$ \\
\hline & $\begin{array}{l}0.2 \mathrm{M} \mathrm{NaCl}+ \\
40 \mathrm{~m} \mathrm{M} \mathrm{CaCl}_{2} \\
\end{array}$ & $0.230 \pm 0.006$ & $0.230 \pm 0.006$ & $0.180 \pm 0.006$ & $0.400 \pm 0.006$ \\
\hline & $\begin{array}{l}0.2 \mathrm{M} \mathrm{NaCl}+ \\
60 \mathrm{mM} \mathrm{NaCl}_{2} \\
\end{array}$ & $0.220 \pm 0.012$ & $0.220 \pm 0.012$ & $0.160 \pm 0.006$ & $0.380 \pm 0.003$ \\
\hline \multirow[t]{4}{*}{6} & Control & $0.307 \pm 0.012$ & $0.390 \pm 0.006$ & $0.200 \pm 0.006$ & $0.390 \pm 0.006$ \\
\hline & $0.2 \mathrm{M} \mathrm{NaCl}$ & $0.120 \pm 0.058$ & $0.130 \pm 0.006$ & $0.130 \pm 0.006$ & $0.070 \pm 0.006$ \\
\hline & $\begin{array}{l}\mathrm{M} \mathrm{NaCl}+40 \\
\mathrm{~m} \mathrm{M} \mathrm{CaCl}_{2}\end{array}$ & $0.353 \pm 0.088$ & $0.45 \pm 0.006$ & $0.250 \pm 0.006$ & $0.480 \pm 0.003$ \\
\hline & $\begin{array}{l}0.2 \mathrm{M} \mathrm{NaCl}+ \\
60 \mathrm{~m} \mathrm{M} \mathrm{NaCl}_{2}\end{array}$ & $0.320 \pm 0.058$ & $0.400 \pm 0.006$ & $0.210 \pm 0.006$ & $0.450 \pm 0.003$ \\
\hline \multirow[t]{4}{*}{9} & Control & $0.303 \pm 0.013$ & $0.570 \pm 0.006$ & $0.290 \pm 0.006$ & $0.480 \pm 0.006$ \\
\hline & $0.2 \mathrm{M} \mathrm{NaCl}$ & $0.200 \pm 0.058$ & $0.250 \pm 0.006$ & $0.190 \pm 0.006$ & $0.116 \pm 0.009$ \\
\hline & $\begin{array}{l}0.2 \mathrm{M} \mathrm{NaCl}+ \\
40 \mathrm{~m} \mathrm{MaCl}_{2}\end{array}$ & $0.486 \pm 0.033$ & $0.680 \pm 0.006$ & $0.310 \pm 0.006$ & $0.540 \pm 0.006$ \\
\hline & $\begin{array}{l}0.2 \mathrm{M} \mathrm{NaCl}+ \\
60 \mathrm{~m} \mathrm{M} \mathrm{NaCl}_{2}\end{array}$ & $0.460 \pm 0.058$ & $0.620 \pm 0.006$ & $0.260 \pm 0.006$ & $0.520 \pm 0.006$ \\
\hline \multirow[t]{4}{*}{12} & Control & $0.456 \pm 0.008$ & $0.690 \pm 0.006$ & $0.37 \pm 0.006$ & $0.590 \pm 0.06$ \\
\hline & $0.2 \mathrm{M} \mathrm{NaCl}$ & $0.276 \pm 0.008$ & $0.250 \pm 0.006$ & $0.313 \pm 0.003$ & $0.180 \pm 0.06$ \\
\hline & $\begin{array}{l}0.2 \mathrm{M} \mathrm{NaCl}+ \\
40 \mathrm{~m} \mathrm{CaCl}_{2} \\
\end{array}$ & $0.573 \pm 0.012$ & $0.683 \pm 0.009$ & $0.420 \pm 0.006$ & $0.630 \pm 0.03$ \\
\hline & $\begin{array}{l}0.2 \mathrm{M} \mathrm{NaCl}+ \\
60 \mathrm{~m} \mathrm{M} \mathrm{NaCl}_{2} \\
\end{array}$ & $0.510 \pm 0.006$ & $0.623 \pm 0.007$ & $0.373 \pm 0.007$ & $0.570 \pm 0.06$ \\
\hline \multirow[t]{4}{*}{15} & Control & $0.570 \pm 0.006$ & $0.756 \pm 0.007$ & $0.490 \pm 0.006$ & $0.670 \pm 0.06$ \\
\hline & $0.2 \mathrm{M} \mathrm{NaCl}$ & $0.353 \pm 0.007$ & $0.320 \pm 0.006$ & $0.356 \pm 0.003$ & $0.240 \pm 0.06$ \\
\hline & $\begin{array}{l}0.2 \mathrm{M} \mathrm{NaCl}+ \\
40 \mathrm{~m} \mathrm{M} \mathrm{CaCl}_{2} \\
\end{array}$ & $0.0680 \pm 0.006$ & $0.74 \pm 0.006$ & $0.820 \pm 0.006$ & $0.770 \pm 0.03$ \\
\hline & $\begin{array}{l}0.2 \mathrm{M} \mathrm{NaCl}+ \\
60 \mathrm{~m} \mathrm{M} \mathrm{NaCl}_{2}\end{array}$ & $0.0646 \pm 0.012$ & $0.680 \pm 0.006$ & $0.740 \pm 0.006$ & $0.710 \pm 0.06$ \\
\hline \multicolumn{2}{|c|}{ Significance } & $* *$ & $* *$ & $* *$ & $* *$ \\
\hline
\end{tabular}

** = Significant difference at $\mathrm{P} \leq 0.01$ according to F-test. Chlorophyll "a" = Chl"a" and Carotein $=$ car.

Egypt. J. Microbiol. 48 (2013) 
BENEFICIAL EFFECTS OF CALCIUM CHLORIDE...

TABLE 2. Effect of two concentrations of $\mathrm{CaCl}_{2}$ on some metabolites of salinized culture of different ages of $\boldsymbol{A}$. constricta.

\begin{tabular}{|c|c|c|c|c|}
\hline $\begin{array}{l}\text { Age } \\
\text { (days) }\end{array}$ & Treatments & $\begin{array}{c}\text { Glucose } \\
\text { ug/ml }\end{array}$ & $\begin{array}{c}\text { Nitrogen } \\
\text { mg N/100 ml }\end{array}$ & $\begin{array}{c}\text { Protein } \\
\mathrm{mg} / 100 \mathrm{ml}\end{array}$ \\
\hline \multirow[t]{4}{*}{3} & Control & $23 \pm 0.250$ & $0.57 \pm 0.006$ & $7.09 \pm 0.012$ \\
\hline & $0.2 \mathrm{M} \mathrm{NaCl}$ & $28 \pm 0.180$ & $0.35 \pm 0.006$ & $5.68 \pm 0.046$ \\
\hline & $0.2 \mathrm{M} \mathrm{NaCl} 40 \mathrm{~m} \mathrm{M} \mathrm{CaCl}{ }_{2}$ & $35.8 \pm 0.320$ & $0.78 \pm 0.006$ & $7.68 \pm 0.063$ \\
\hline & $\begin{array}{l}0.2 \mathrm{M} \mathrm{NaCl}+60 \mathrm{~m} \mathrm{M} \\
\mathrm{NaCl}_{2}\end{array}$ & $35.2 \pm 0.610$ & $0.60 \pm 0.006$ & $7.08 \pm 0.004$ \\
\hline \multirow[t]{4}{*}{6} & Control & $44.8 \pm 0.810$ & $1.20 \pm 0.060$ & $8.29 \pm 0.006$ \\
\hline & $0.2 \mathrm{M} \mathrm{NaCl}$ & $36 \pm 0.580$ & $0.75 \pm 0.06$ & $6.74 \pm 0.063$ \\
\hline & $\begin{array}{l}0.2 \mathrm{M} \mathrm{NaCl}+40 \mathrm{~m} \mathrm{M} \\
\mathrm{CaCl}_{2}\end{array}$ & $55 \pm 0.580$ & $1.52 \pm 0.060$ & $10.34 \pm 0.063$ \\
\hline & $0.2 \mathrm{M} \mathrm{NaCl}+60 \mathrm{mM} \mathrm{NaCl} 2$ & $47 \pm 0.580$ & $1.30 \pm 0.003$ & $12.2 \pm 0.115$ \\
\hline \multirow[t]{4}{*}{9} & Control & $62.4 \pm 0.660$ & $1.91 \pm 0.006$ & $8.5 \pm 0.057$ \\
\hline & $0.2 \mathrm{M} \mathrm{NaCl}$ & $57 \pm 0.580$ & $1.20 \pm 0.110$ & $13.2 \pm 0.058$ \\
\hline & $0.2 \mathrm{M} \mathrm{NaCl}+40 \mathrm{mM} \mathrm{CaCl}_{2}$ & $88.6 \pm 0.330$ & $2.11 \pm 0.009$ & $11.61 \pm 0.063$ \\
\hline & $\begin{array}{l}0.2 \mathrm{M} \mathrm{NaCl}+60 \mathrm{~m} \mathrm{M} \\
\mathrm{NaCl}_{2}\end{array}$ & $84 \pm 0.580$ & $1.97 \pm 0.006$ & $15.4 \pm 0.067$ \\
\hline \multirow[t]{4}{*}{12} & Control & $94.6 \pm 0.580$ & $2.42 \pm 0.006$ & $10.0 \pm 0.577$ \\
\hline & $0.2 \mathrm{M} \mathrm{NaCl}$ & $84 \pm 0.580$ & $1.51 \pm 0.020$ & $16.4 \pm 0.067$ \\
\hline & $\begin{array}{l}0.2 \mathrm{M} \mathrm{NaCl}+40 \mathrm{~m} \mathrm{M} \\
\mathrm{CaCl}_{2}\end{array}$ & $128 \pm 0.580$ & $2.80 \pm 0.060$ & $13.18 \pm 0.091$ \\
\hline & $\begin{array}{l}0.2 \mathrm{M} \mathrm{NaCl}+60 \mathrm{~m} \mathrm{M} \\
\mathrm{NaCl}_{2}\end{array}$ & $119 \pm 0.580$ & $2.50 \pm 0.115$ & $17.21 \pm 0.063$ \\
\hline \multirow[t]{4}{*}{15} & Control & $120.4 \pm 0.580$ & $3.10 \pm 0.115$ & $14.4 \pm 0.067$ \\
\hline & $0.2 \mathrm{M} \mathrm{NaCl}$ & $130 \pm 0.580$ & $1.70 \pm 0.060$ & $18.2 \pm 0.067$ \\
\hline & $\begin{array}{l}0.2 \mathrm{M} \mathrm{NaCl}+40 \mathrm{~m} \mathrm{M} \\
\mathrm{CaCl}_{2}\end{array}$ & $160 \pm 0.580$ & $3.68 \pm 0.060$ & $16.6 \pm 6.057$ \\
\hline & $\begin{array}{l}0.2 \mathrm{M} \mathrm{NaCl}+60 \mathrm{~m} \mathrm{M} \\
\mathrm{NaCl}_{2}\end{array}$ & $151 \pm 0.580$ & $3.22 \pm 0.060$ & $11.44 \pm 0.122$ \\
\hline \multicolumn{2}{|r|}{ Significance } & $* *$ & $* *$ & $* *$ \\
\hline
\end{tabular}

$* *=$ Significant difference at $\mathrm{P} \leq 0.01$ according to F-test. 
TABLE 3. Effect of two concentrations of $\mathrm{CaCl}_{2}$ on some metabolites activities of salinized cultures of different ages of $N$. linckia.

\begin{tabular}{|c|c|c|c|c|}
\hline $\begin{array}{c}\text { Age } \\
\text { (days) }\end{array}$ & Treatments & $\begin{array}{c}\text { Total glucose } \\
\text { ug/ml }\end{array}$ & $\begin{array}{c}\text { Total nitrogen } \\
\text { mg N/100 ml }\end{array}$ & $\begin{array}{c}\text { Total protein } \\
\mathrm{mg} / 100 \mathrm{ml}\end{array}$ \\
\hline \multirow[t]{4}{*}{3} & Control & $32.63 \pm 0.66$ & $0.56 \pm 0.06$ & $3.8 \pm 0.17$ \\
\hline & $0.2 \mathrm{M} \mathrm{NaCl}$ & $29 \pm 0.58$ & $0.34 \pm 0.06$ & $4.2 \pm 0.12$ \\
\hline & $\begin{array}{l}0.2 \mathrm{M} \mathrm{NaCl}+40 \mathrm{~m} \mathrm{M} \\
\mathrm{CaCl}_{2}\end{array}$ & $52.6 \pm 1.20$ & $0.6 \pm 0.06$ & $4 \pm 0.06$ \\
\hline & $\begin{array}{l}0.2 \mathrm{M} \mathrm{NaCl}+60 \mathrm{mM} \\
\mathrm{NaCl}_{2}\end{array}$ & $43 \pm 0.58$ & $0.54 \pm 0.06$ & $4 \pm 0.12$ \\
\hline \multirow[t]{4}{*}{6} & Control & $40.53 \pm 0.57$ & $0.72 \pm 0.006$ & $4 \pm 0.058$ \\
\hline & $0.2 \mathrm{M} \mathrm{NaCl}$ & $43 \pm 0.58$ & $0.63 \pm 0.006$ & $4.2 \pm 0.115$ \\
\hline & $\begin{array}{l}0.2 \mathrm{M} \mathrm{NaCl}+40 \mathrm{~m} \mathrm{M} \\
\mathrm{CaCl}_{2}\end{array}$ & $61 \pm 0.58$ & $0.96 \pm 0.006$ & $3.21 \pm 0.121$ \\
\hline & $\begin{array}{l}0.2 \mathrm{M} \mathrm{NaCl}+60 \mathrm{mM} \\
\mathrm{NaCl}_{2}\end{array}$ & $50 \pm 0.58$ & $0.84 \pm 0.006$ & $5.4 \pm 0.230$ \\
\hline \multirow[t]{4}{*}{9} & Control & $65.3 \pm 0.124$ & $1.12 \pm 0.023$ & $6.45 \pm 0.030$ \\
\hline & $0.2 \mathrm{M} \mathrm{NaCl}$ & $51.67 \pm 0.667$ & $0.6 \pm 0.251$ & $4.93 \pm 0.38$ \\
\hline & $\begin{array}{l}0.2 \mathrm{M} \mathrm{NaCl}+40 \mathrm{~m} \mathrm{M} \\
\mathrm{CaCl}_{2}\end{array}$ & $95 \pm 0.577$ & $1.52 \pm 0.058$ & $9.6 \pm 0.036$ \\
\hline & $\begin{array}{l}0.2 \mathrm{M} \mathrm{NaCl}+60 \mathrm{~m} \mathrm{M} \\
\mathrm{NaCl}_{2}\end{array}$ & $86 \pm 0.577$ & $4.31 \pm 3.24$ & $7.8 \pm 0.058$ \\
\hline \multirow[t]{4}{*}{12} & Control & $95.4 \pm 0.230$ & $1.5 \pm 0.058$ & $9.4 \pm 0.00$ \\
\hline & $0.2 \mathrm{M} \mathrm{NaCl}$ & $81 \pm 0.577$ & $1.14 \pm 0.058$ & $6.4 \pm 0.230$ \\
\hline & $\begin{array}{l}0.2 \mathrm{M} \mathrm{NaCl}+40 \mathrm{~m} \mathrm{M} \\
\mathrm{CaCl}_{2}\end{array}$ & $125 \pm 0.577$ & $1.8 \pm 0.058$ & $12.13 \pm 0.075$ \\
\hline & $\begin{array}{llll}0.2 \mathrm{M} & \mathrm{NaCl} & +60 \mathrm{~m} \quad \mathrm{M} \\
\mathrm{NaCl}_{2} & & & \\
\end{array}$ & $101 \pm 0.577$ & $1.43 \pm 0.044$ & $10.16 \pm 0.08$ \\
\hline \multirow[t]{4}{*}{15} & Control & $126.33 \pm 0.190$ & $2 \pm 0.077$ & $13.6 \pm 0.346$ \\
\hline & $0.2 \mathrm{M} \mathrm{NaCl}$ & $116.55 \pm 0.293$ & $1.4 \pm 0.058$ & $9.11 \pm 0.063$ \\
\hline & $\begin{array}{l}0.2 \mathrm{M} \mathrm{NaCl}+40 \mathrm{~m} \mathrm{M} \\
\mathrm{CaCl}_{2}\end{array}$ & $146 \pm 0.577$ & $2.32 \pm 0.058$ & $16.13 \pm 0.075$ \\
\hline & $\begin{array}{l}0.2 \mathrm{M} \mathrm{NaCl}+60 \mathrm{~m} \mathrm{M} \\
\mathrm{NaCl}_{2}\end{array}$ & $129.33 \pm 1.201$ & $2.1 \pm 0.058$ & $15.6 \pm 0.057$ \\
\hline \multicolumn{2}{|c|}{ Significance } & $* *$ & N.S & $* *$ \\
\hline
\end{tabular}

** = Significant difference at $\mathrm{P} \leq 0.01$ and N.S. =non significant according to F-test 
Protein electrophoresis pattern of A. constricta

As shown in Fig. 3 and Table 4 the structural pattern of the $0.2 \mathrm{M} \mathrm{NaCl}$ treated culture after 15 days showed the disappearance of a protein with an apparent molecular weight of $77 \mathrm{KDa}$ that had been present in the control track (Fig. 3, Table 4). At the same time two proteins at 171 and $70 \mathrm{KDa}$ appeared. Addition of $0.04 \mathrm{M} \mathrm{CaCl}_{2}$ to salinized culture (with $0.2 \mathrm{M} \mathrm{NaCl}$ ) of $A$. constricta showed the disappearance of one protein at $77 \mathrm{KDa}$ and the appearance of three protein bands at 17, 61 and $162 \mathrm{KDa}$. The treatment with $60 \mathrm{mM} \mathrm{CaCl}_{2}$ produced three protein bands with an apparent 18,58 and $138 \mathrm{KDa}$ as compared with salinized culture alone after 15 days old.

\section{Protein electrophoresis pattern of $N$. linckia}

The $0.2 \mathrm{M} \mathrm{NaCl}$ treated culture showed no major changes of protein patterns as compared with control (Fig. 4 and Table 4). The culture of $0.2 \mathrm{M} \mathrm{NaCl}$ produced two proteins with apparent protein profiles with 44 and $6 \mathrm{KDa}$ that also, was evidenced in control track, but the difference between them was in the percentage of intensity. Addition of 40 or $60 \mathrm{mM} \mathrm{CaCl}_{2}$ to salinized culture of $N$. linckia also produced the same proteins with an apparent 43 and $6 \mathrm{KDa}$ that differed only in the percentage of intensity.

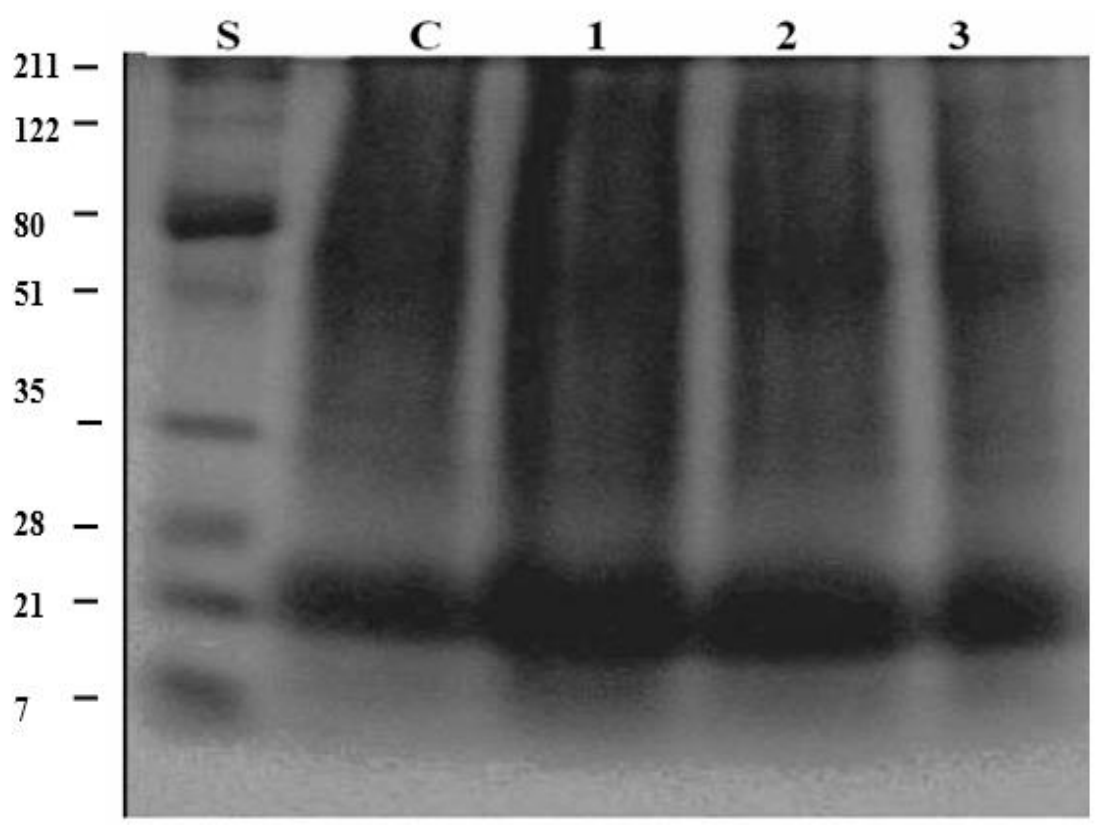

Fig. 3. Photographic picture of the gel electrophoresis of protein in A. constricta. [Lane S=Standard, $\mathrm{C}=$ Control , Lane $1=0.2 \mathrm{M} \mathrm{NaCl}$, Lane $2=0.2 \mathrm{M}$

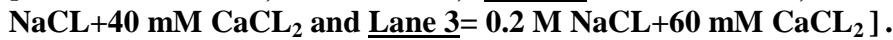


TABLE 4. The relative intensity (percent) of molecular weights (M. wt.) representing protein bands for $A$. constricta and $N$. linckia after 15 days incubation.

\begin{tabular}{|c|c|c|c|c|c|c|c|c|c|c|}
\hline \multirow{5}{*}{ 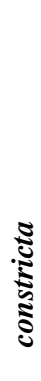 } & \multirow[t]{2}{*}{ Bands } & \multicolumn{2}{|c|}{ Control } & \multicolumn{2}{|c|}{$0.2 \mathrm{M} \mathrm{NaCl}$} & \multicolumn{2}{|c|}{$\begin{array}{c}0.2 \mathrm{M} \mathrm{NaCl} \\
+ \\
40 \mathrm{mM} \\
\mathrm{CaCl}_{2}\end{array}$} & \multicolumn{2}{|c|}{$\begin{array}{c}0.2 \mathrm{M} \mathrm{NaCl} \\
+ \\
60 \mathrm{mM}^{-} \\
\mathrm{CaCl}_{2}\end{array}$} & \multirow{2}{*}{$\begin{array}{c}\text { Standard } \\
\text { M. wt } \\
\text { (KDa) }\end{array}$} \\
\hline & & $\begin{array}{l}\mathbf{A M} \\
\mathbf{T} \%\end{array}$ & $\begin{array}{l}\text { M. } \\
\text { wt }\end{array}$ & $\begin{array}{c}\text { AMT } \\
\%\end{array}$ & $\begin{array}{l}\text { M. } \\
\text { wt }\end{array}$ & $\underset{\%}{\mathbf{A M T}}$ & $\begin{array}{l}\text { M. } \\
\text { wt }\end{array}$ & $\begin{array}{l}\mathbf{A M} \\
\mathbf{T} \%\end{array}$ & $\begin{array}{l}\text { M. } \\
\text { wt }\end{array}$ & \\
\hline & 1 & 46.98 & 77 & 4.03 & 171 & 4.74 & 162 & 14.06 & 138 & 211 \\
\hline & 2 & 4.22 & 37 & 65.84 & 70 & 4.1 & 70 & 1.95 & 70 & 122 \\
\hline & 3 & 3.19 & 33 & 5.79 & 36 & 16.01 & 61 & 17.51 & 58 & 80 \\
\hline & 4 & 45.61 & 19 & 3.2 & 32 & 1.77 & 36 & 1.1 & 36 & 51 \\
\hline & 5 & & & 21.11 & 19 & 1.56 & 33 & 1.42 & 33 & 35 \\
\hline & 6 & & & & & 71.82 & 17 & 63.97 & 18 & 28 \\
\hline : & 1 & 32.44 & 44 & 16.34 & 44 & 68.61 & 43 & 39.82 & 43 & 211 \\
\hline $\begin{array}{l}i= \\
\dot{z}\end{array}$ & 2 & 67.56 & 6 & 83.66 & 6 & 31.39 & 6 & 60.18 & 6 & 122 \\
\hline
\end{tabular}

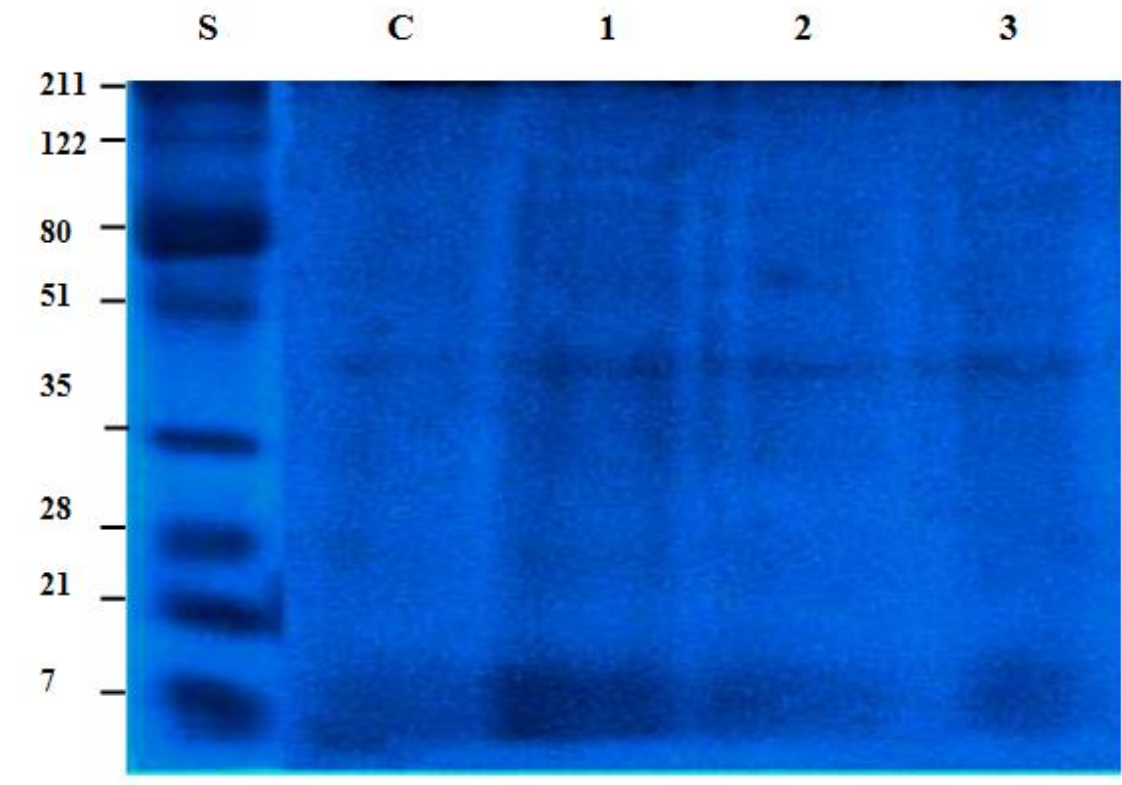

Fig. 4. Photographic picture of the gel electrophoresis of protein in N. linckia. [ Lane $\mathrm{S}=$ Standard, $\mathrm{C}=$ Control, Lane $1=0.2 \mathrm{M} \mathrm{NaCl}$, Lane $2=0.2 \mathrm{M} \mathrm{NaCL}+40 \mathrm{mM}$ $\mathrm{CaCL}_{2}$ and Lane 3=0.2M NaCL$\left.+60 \mathrm{mM} \mathrm{CaCL}_{2}\right]$.

Egypt. J. Microbiol. 48 (2013) 


\section{Discussion}

The addition of $0.2 \mathrm{M} \mathrm{NaCl}$ to culture media of $A$. constricta and $N$. linckia caused a significant decrease in cell number, dry weight, optical density and different pigments. The results obtained agreed with Blumwald \& Tel-or (1984), who observed that, the chlorophyll contents of Synechococcus 6311 was essentially stable through the process of salt adaption, with an observed enhancement in the synthesis of biloprotein pigments (phycocyanin and phycoerythrin). There was an enhancement in the synthesis of salt adapted cells of synechococcus 6311, while they indicated that the synthesis of both pigments in the heterocystous $N$. muscorum was slightly lower at high salt concentration of $\mathrm{NaCl}$. The growth rate of Porphyridium cruentum was influenced by $\mathrm{NaCl}$. Optimum growth was found with salinities ranging between $0.45 \mathrm{M}$ and $0.8 \mathrm{M}$ $\mathrm{NaCl}$. A further increase in salinity to $1.5 \mathrm{M} \mathrm{NaCl}$ resulted in a drastic drop in algal growth (Lee et al., 1989).

The combination of low concentrations of $\mathrm{CaCl}_{2}$ (40 or $60 \mathrm{mM}$ ) with salinized culture $(0.2 \mathrm{M} \mathrm{NaCl})$ of $A$ constricta and $N$. linckia, caused a significant increase in the growth parameters and metabolic activity as compared with control $(0.2 \mathrm{M} \mathrm{NaCl}$ only). In accordance with the present results, Ahmed et al. (1989) found that the growth of Chlorella vulgaris was markedly inhibited with the rise of $\mathrm{NaCl}$ level. However, a marked growth stimulation was observed under certain combinations of $\mathrm{NaCl}$ and $\mathrm{CaCl}_{2}$.

Calcium chloride at $(0.2 \mathrm{~g} / \mathrm{l})$ favoured germination process and a zero concentration of $\mathrm{CaCl}_{2}$ hindered germination of Anabaena sp. (Shivaprakash et al., 2004). Biomass through the sporulation and germination cycle was 50 times more than 20 times increases in continuous vegetative growth.

The mechanism of $\mathrm{Ca}$ in stressed plants could be activated through membrane stability (Munns et al., 1983). Also low Ca increases membrane permeability at high external $\mathrm{NaCl}$ (Greenway \& Munns, 1980). Leopold \& Wilting (1984) found that $\mathrm{Ca}$ served partially to protect tissues from $\mathrm{NaCl}$ damage and lessens the leakiness of organic metabolites. Therefore, it could be generalized that $\mathrm{Ca}$ relief occurs in the following sequence: Stabilization and repair of $\mathrm{NaCl}$ damaged membrane including thylakoids, less uptake of $\mathrm{Na}^{+}$(less toxicity) and preservation of cell metabolites from leakiness. The carotenoid and polysaccharides content were increased to eliminate free radical and regulate osmotic pressure (Bi Yonghong et al., 2005).

Many organisms are respond to shock treatment by synthesizing a new set of proteins (Bhagwat \& Apte, 1989; Schubert et al.,1993; Thomas et al., 1990 and Rajeshwar \& Donat, 1996). The synthesis of cellular metabolites in response to salt stress by halotolerant and halosensitive $N$. muscorum were grown at varying levels of $\mathrm{NaCl}$ in liquid medium were studied by Shobhana \& Kaushik (2002). Also, they stated that protein synthesis was stimulated up to $0.05 \mathrm{M} \mathrm{NaCl}$ only in the halotolerant strain. Qualitative changes in protein showed the presence of salt 
sensitive protein $(37 \mathrm{kDa})$ and emergence of $42.5,27$ and $72 \mathrm{kDa}$ proteins that provide tolerance to the halotolerant strain. Our results indicate that the cyanobacteria $A$. constricta and $N$. linckia responded to shock treatments be producing electrophoresis pattern of both organisms under shock of $0.2 \mathrm{M} \mathrm{NaCl}$ alone or with addition of 40 or $60 \mathrm{mM} \mathrm{CaCl} 2$ provided major changes (appearance disappearance) of protein patterns. Our results are similar to those of El-Naggar et al. (2005) who found disappearance of some protein bands (76, 42 and $39 \mathrm{KDa}$ ) for $A$. subcylindica as compared with the control. Addition of $\mathrm{CaCl}_{2}$ to the salinized culture caused the reappearance of these bands. The $40 \mathrm{KDa}$ proteins appeared in both salt and salt-calcium treated cells.

Any substantial increase in salt stress in nature will affect the ecological and economically important cyanobacterial communities. These communities will be in turn affect the productivity of higher plants. Where cyanobacteria are being considered as an alternate natural source of nitrogenous fertilizers for rice paddies and other crops. Finally to keep salt levels in water not rise too high, we must add $\mathrm{Ca}^{+2}$ to water to antagonize the harmful effects of salt on cyanobacterial communities.

\section{References}

Ahmed, A. M., Radi,A.F., Haikl,M.D. and Abdel-Basset, R. (1989) Effect of Na-Ca combination on photosynthesis and some realated processes of Chlorella. J. Plant Physiol. 135, 175-178.

Anand, N., Hopper, R.S.S., Jagatheswari, G., Kaehyap, A.K. and Kumar, H.D. (1994) Response of certain blue- green alga (cyanobacteria) to salinity. Indian Recent Advances -In Phycology, 22-29.

Battah, M.G. and Khalil, A.H. (2008) Priliminary observations on soil algae in Sana'a Governorate (Yemen). Assiut University J. Botany, 37 (1), 35-45.

Bennett, A. and Bogorad, L. (1973) Complementary chromatic adaptation in a filamentous blue - green algae. J. Cell Biol. 58, 419- 435.

Bhagwat, A.A. and Aptes, S.K. (1989) Comparative analysis of proteins induced by heat shock, salinity and osmotic stress in the nitrogen- fixing cyanobacterium Anabaena sp. strain L-31. J. Bacterial. 171, 5187-5189.

Bi YongHong, Deng Zhong Yang, Hu Zheng Yu and Xu Min (2005) Response of Nostoc flagelliforme to salt stress. Acta Hydrobiologica Sinica, 29(2)125-129.

Blumwald, E. and Tel- Or, E. (1984) Salt adaptation of the cyanobacterium Synechococcus 6311 growing in continuous culture (turbidostat). Plant Physiol. 74, 183 - 185.

El-Naggar, A.H., Osman M.E.H., El-Sheekh, M.M. and Makled, M.M.F. (2005) Ameliorative effect of calcium on the nitrogen metabolism changes induced by salinity in Anabeana subcylidrica. International J. Agri. Biol. 7(2), 247-252. 
Brownell, P. F. and Nicholas, D.J. (1967) Some effects of sodium on nitrate assimilation and $\mathrm{N}_{2}$ fixation in Anabaena cylindrical, Plant Physiology, 73, 377-380.

Greenway, H. and Munns, R. (1980) Mechanisms of salt tolerance in non-halophytes; Ann. Rev. Plant Physiol. 31, 149- 190.

Hagen, C., Grunewald, K., Xylander, M. and Rothe, E. (2001) Effect of cultivation parameters on growth and pigment biosynthesis in flagellated cells of Haematococcus pluvialis. J. Appl. Phycol. 13, 79-87.

Jacobs, M.B. (1958) "The Chemical Analysis of Food Products”, D. Van. Nostrand Co. Inc. New York. p. 34

Jeffrey, S.W. and Humphrey, G.F. (1975) New spectrophotometric equations for determining chlorophyll a,b, c, and c2 in higher plants, algae and natural phytoplankton. Biochem. Physiol. P Flanz. 167-191.

Jensen, A. and Liaaen Jensen, S. (1959) Quantitative paper chromatography of Acta Chem. Scand. 13, 1813.

Laemmli, U. K. (1970) Clevage of the structural proteins during the assembly of the head of the bacteriophage T4. Nature, 277, 680- 685 .

Lee, Y.K., Tan, H.M. and Low, C. S. (1989) Effect of medium on cellular fatty acid composition of marine alga Porphyridium cruentum (Rhodophyceae). J. Appl. (1) 1923.

Lefort-Tran, M., Spath, S. and Packer, L. (1988) Cytoplasmic membrane changes during adaptation of the fresh water cyanobacterium Synechococcus sp. 6311 to salinity. Plant Physiol. 87,767-775.

Leganes, F., Sanchez-Maeso, E. and Fernandez-Valint, E. (1987) Effect of indol acetic acid on growth and dinitrgen fixation by blue green algae. Seven. Bot. Tidskr. 64, 460461.

Leopold, A.C. and Willing, R.P. (1984) Evidence for toxicity effects of salt on membranes. In: "Salinity Tolerance in Plants, Strategies For Crop Improvement", Staples, R.C. and Toennissen,G.H. (Ed.). pp.67-91. A Wiley-Interscience Publication. John Wiley \& Sons, New York, Chichester, Brisbane, Toronto, Singapore,

Lowery, O.H. Rosenbrough, N.J., Farr, A.L. and Randall, R.J. (1951) Protein measurements with folin phenol reagent. J.Biol. Chem. 193,265-270.

Masojidek, J., Torzillo, G., Kopecky, J., Koblizek, M., Nidiaci, L., Komenda, J., Lukavska, A. and Sacchi, A. (2000) Changes in chlorophyll fluorescence quenching and pigment composition in the green alga Chlorococcum sp. grown under nitrogen deficiency and salinity stress. J. Appl. Phycol. 12, 417-426.

Munns, R., Greenway, H. and Kirst, G.O. (1983) Halotolerant eukaryotes. In: "Encyclopedia of Plant Physiol." 12C, Lange, O.I., Nobel. P.S., Osmond, C. B. and Zeigler, H. (Ed.). pp.59-136. Springer-Verlag, Berlin, Heidelberg, New York. 
Naguib, M. I. (1963) Colorimetric estimation plant polysaccharides. Zucher, 16, 15-18.

Rai, A. K. and Abraham, G. (1993) Salinity tolerance and growth analysis of the cyanobacterium Anabaena dolioum. Bull. Environ.Toxicol. 51, 724- 731.

Sinha, Rajeshwar P. and Hader Donat, P. (1996) Response of a rice field cyanobacterium Anabaena sp. to physiological stressors. Environmental and Experimental Botany, 36(2), 147 - 155.

Reed, R.H., Borowitzka, L.J., Mackay, M.A., Chudek, J.A., Foster, R., Warr, S.R.C., Moore, D.J. and Stewart, W.D.P. (1986) Organic Solute accumulation in osmotically stressed cyanobacteria. FEMS Microbiol. Rev. 39, 51-56.

Schubert, H., Fulda, S. and Hagemann, M. (1993) Effects of adaptation to different salt concentrations on photosynthesis and pigmentation of the cyanobacterium Synechocystis sp. Pcc 6803. J. Plant Physiol. 142, 291-295.

Shobhana G. and Kaushik, B.D. (2002) Synthesis of cellular metabolites in response to salt stress by halotolerant and halosensetive Nostoc muscrum. Indian Journal of Microbiology, 42 (2) 101-106.

Shivaprakash,M.K.,Vidya Kulkarni and Binu Koshy (2004) Effect of physicochemical parameters on akinete differentiation and germination and its application in biomass production in Anabaena sp. Biofertilizers Technology for Rice Based Cropping System, 102-110.

Snedecor, G.W. and Cochran, W.G. (1982) "Statistical Methods" $6^{\text {th }}$ ed.Iawa, USA.

Thomas, S.P., Zaritsky, A. and Boussiba, S. (1990) Ammonia extraction by an, Lmethionine -DL-Sulfoximine - resistant mutant of the rice field cyanobacterium Anabaena siamensis. App. Environ. Microbial. 56, 3499-3504.

Zhao Xue Min, Bi Yong Hong, Qin Shan and Hu Zheng Yu (2005) The response of cultivated Nostoc flagelliforme to salt stress. Acta Batanica Boreali-Occidentalia Sinica, 25(11), 2234 - 2239. 


\section{التأثيرات الايجابيه لكلوريا الكالسيوم على نوعين من الطحالب أبلى

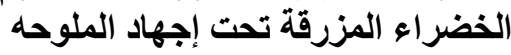

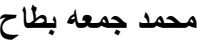

قسم النبات - كلية العلوم - جامعة بنهاح- بنها ــصر.

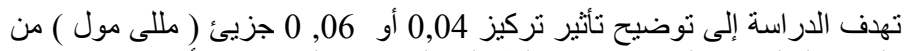

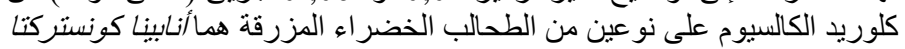

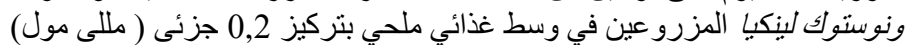

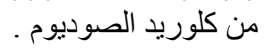

أوضحت النتائج أن 0,2 جزئ من كلوريد الصوديوم يحدث تأثير معنويا

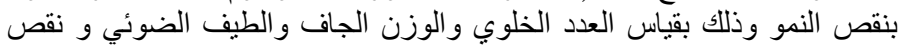

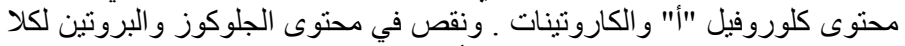

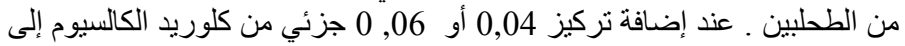
الطحلبين والمزروعين في وسط غذائي به

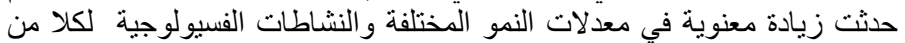
الطحلبين .

أظهرت نتائج تحليل البروتين لطحلب أنابينا كونستركتا و الذي تمت معاملته أبروته

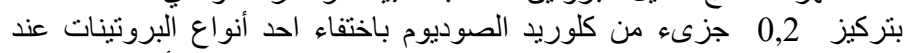

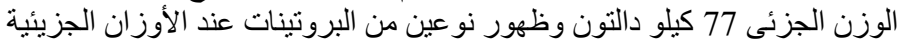

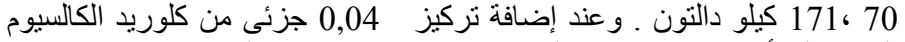

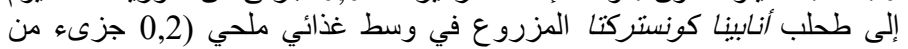

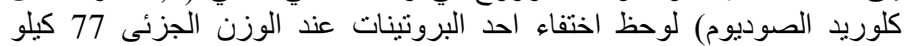

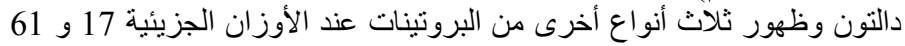

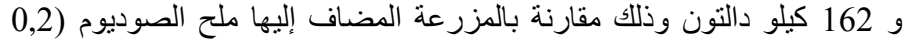

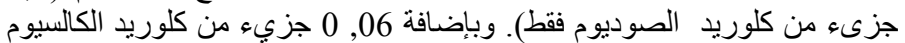

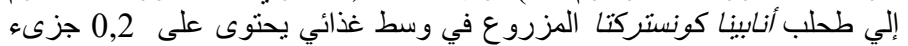

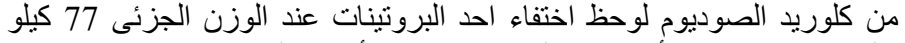

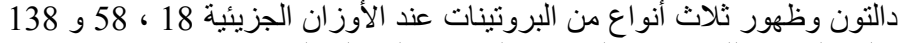

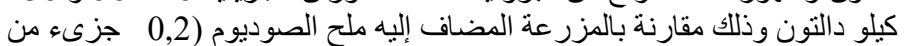
كلوريد الصوديوم فقط) . كلئ

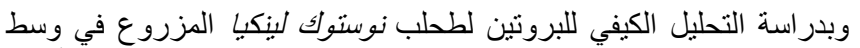

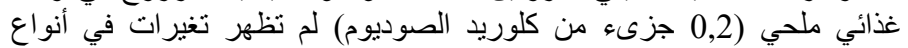

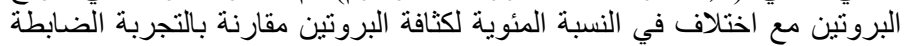

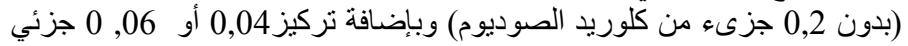

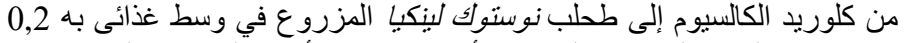

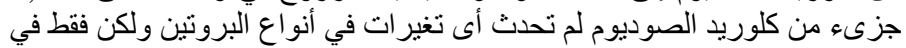

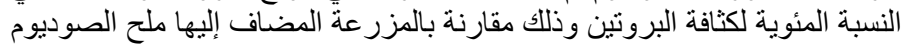

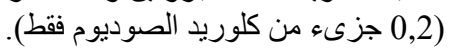

